\title{
PERSIAN GYNAECOLOGY
}

THE history of the practice of medicine in Persia has been widely studied. Everybody knows at least by name the great clinicians Avicenna, Rhazes, and Haly Abbas. Even a few who lived after the Mongol Invasion are not unknown. The story of surgery in these regions is also better known now than it was thanks to a magnificent reproduction with miniatures in colour of Sharaf-ul-Din's translation of Abulcasis on surgery ${ }^{1}$ and a recent publication by the Pergamon Press of a hitherto unknown work by an army surgeon of the seventeenth century. ${ }^{2}$

But as yet no one has studied the history of the gynaecology of those times. This is quite unreasonable because sections on diseases of women are to be found in all the big text-books of medicine. There are even half a dozen miniatures illustrating pelvic operations in Sharaf-ul-Din's book.

In my opinion what represents the text-books of gynaecology of those days has passed unrecognized. The reason for this is that the subject of disease in women in Persian monographs was always discussed from an angle different from that of disease in men. These monographs have been neglected and overlooked by serious students, for they smack of pornography. They were read and studied largely on account of this feature. Such as have been translated into any European language have been translated solely with this in mind.

To the Persians of old the sexual act was never indecent. To read and write about such things was considered no more improper than to study in detail today the menu of a smart restaurant. Both stimulate the appetite. Such anti-morality laws as from time to time were thrust upon an unwilling people, were not because fornication or adultery were considered improper but because the houses in which these were practised were usually houses where illegal alcohol was to be obtained, where unruly villains were apt to consort, and because such houses were the source of plots against the State and of disturbances to the public peace.

Now, Persian literature which might today be called indecent, falls into one of three categories. First there are the classical poets, who usually wrote long poems on love and to heighten the description of the charms of the beloved from time to time introduce passages not acceptable to the modern reader. A translator of today glosses over such lines or inserts a few asterisks. They are not essential to the story and their exclusion does not violate the text. Their value is only to add drama and emphasis to his description. In no sense can these poems be called pornographic, scarcely even erotic.

The next type of 'indecent literature' was that class of writing known as Hazaliyat or Tayyibat, words meaning bawdy or ribald tales. These do indeed depend upon sex for their point and for their attraction. They are, says Professor Browne, ${ }^{3}$ almost without exception unfit for translation and are regarded with disapproval or disgust by all respectable Persians at the present day. Of the famous writers of this type of literature the earliest are Azraqi of Herat (died 1132) and Suzani (died 1173). The

1 Le Premier Manuscrit Chirurgical Turc, ed. by Charaf ed-Din, Paris, Roger Dacosta, 1960,

C. Elgood, 'Safavid Surgery', Analecta Medico-Historica, Oxford, Pergamon Press, 1966.

' E. G. Browne, Literary History of Persia, Cambridge, 1924, vol. iii, p. 239. 


\section{Texts and Documents}

former also illustrated his poem entitled De Mentula et Vulva (Alfiya Shalfiya). Except that this poem acted as a strong aphrodisiac and cure for the prince Tughan-shah, this type of literature possesses no medical interest. The most famous of all these writers of Hazaliyat was 'Ubayd-i-Zakani (died 1371). Perhaps his name should live in medical history on account of the following epigram upon an unpopular physician.

To this fool doctor no man need apply

For treatment, if he does not wish to die.

At last to him the Death Angel appears

Saying: Buy now the goods you've sold for years.

In yet a third category of the so-called indecent literature are many medical manuals. These I consider represent medieval Persian text-books of gynaecology. They being concerned with matters relating to women, are usually considered pornographic and are placed in the 'Reserve' in European libraries. Indian and Persian librarians show greater wisdom, for they classify such works as medical and set them upon an open shelf.

Possibly the first Persian to produce one of these quasi-scientific works was Samu'l bin Yahya al-Maghrabi. Born about the beginning of the twelfth century in Spain or Morocco, he fled to Baghdad, probably on account of religious persecution, and finally settled in Meragha. Here he wrote a medical work called Kitab-ul-Mufid (The Useful Book) and later the Nuzhat-ul-Ashab $f i M^{\prime}$ 'ashurat-il-Ahabab (The Delight of Comrades in the Conversation of Friends). The first part of this second work according to modern views would be written off as pornographic: the second part is strictly gynaecological. Inside the cover of a copy preserved in the Escorial Library a medieval reader has written: 'Tractatus . . medico-anatomicus de mulieribus, ubi scelestissimus ac impudentissimus author agit de mulierum conversatione, de earum venustate, de mediis illas lucrandi eisque placendi, de requisitis illarum, quae sunt appetendae, reprobandaeve, de earum ornatu, vestitu, de modo componendi fucos, de medicamentis, cibo, potu ad venerem ciendam, de modo impediendi conceptionem procurandive abortum, atque de aliis impudentissimis rebus ad coitum pertinentibus, quas ego ob verecundiam praetermitto'.

The fact is that these Persian writers treat woman from every point of view, as an interesting living whole, not as a dull pathological specimen. They realize that the majority of women are not sick, that they enjoy certain activities which they share with men and which man could not enjoy were it not for their healthy co-operation. It is important therefore that these normal and natural functions be discussed and their enjoyment to the maximum be made possible. All that interferes with the enjoyment of the male reacts upon the female and if it can be put right, it is the duty of her doctor to put it right. To discuss all this in ordinary terms impinges upon the realm of erotic literature. Hence European critics, taking only the chapters which deal with this part of woman's economy, condemn the whole book as pornographic. Just as though a Persian critic were to make selections from, say, the Kinsey Report and, neglecting the objective and the remainder of the Report, were to condemn the whole as a work of pornography and of no scientific value.

It must be admitted, however, that the Persian authors are partly responsible for this opinion. The exciting names which they give to such manuals act like the 


\section{Texts and Documents}

lurid cover of an American sex magazine. Much of their language is not couched in very scientific phrases. It is clear that the writer hoped to push his sales (to use a modern expression) by an injudicious mixture of sex and science.

The blame for this evil reputation, in England at least, lies also very largely with Lady Burton, whose frenzy in destroying one of her husband's translations has produced a story which condemns all books of this class as too grossly indecent for any respectable person to read. The book in question, The Perfumed Garden of Shaykh al-Nafzawi, is not Safavid nor even Persian, and is not a very good example of these gynaecological works. Of course they vary in the amount of medical knowledge that they contain. The Perfumed Garden contains very little. Out of twenty-two chapters at least fourteen have no medical value and no interest other than pornographic. The book has been translated both into French and into English.,5 But it is not to be recommended as an example of medieval Persian gynaecology.

Before going on to describe one of these manuals in detail it is well to give a sketch of what it is likely to contain. The opening chapters often describe the anatomy of the female pelvis and give a short sketch of the physiology and psychology of the female sex. This means a discussion on the temperaments found in women, on what renders a woman pleasing to a man and on various subjects that affect a woman, such as menstruation, body odours, growth of hair, and similar details.

Then may follow a description of such parts of a man as come into contact with a woman, how to increase or diminish their size, and how to increase the pleasure of union. Then there will be a chapter on diseases of the uterus and of the organs of generation, how to strengthen the sexual powers, and what will harm or weaken these. There may well be a discussion on gonorrhoea and syphilis. Mention of this latter disease is an important point in dating the manuscript. For syphilis was described in Persia for the first time in 1505 and was then thought to be a form of anthrax or smallpox. By 1550 it was well known and had received its own name, Atishak (the little fire).

An extremely interesting section often follows which treats of pregnancy, how to ensure it and how to avoid it, and then discusses the various ways of diagnosing the sex of the unborn child. Then come a full description of birth control and the methods of procuring an abortion. Finally all these manuals contain an extensive section on drugs, mainly aphrodisiacs, of course, and very often instructions on how to produce analgesia and even anaesthesia.

Later writers often fail to stick to their last and indulge in a more or less intricate discussion on alcohol and wine, the historical associate of women. There is, for instance, a well-known manual of this class called Tuhfat-ul-'Ashiqqin (the Gift of Lovers). Part two of this work is normal erotic gynaecology. Part one, however, is entirely concerned with wine-drinking - how and when to drink, the virtues of various wines and so forth. This book, of which the author is not known, has gained an undeserved reputation by adding as a subtitle 'The Experiences of Avicenna'. Needless to say it has nothing to do with Avicenna and must have been written several hundred years after the death of the Shaykh-ul-Re'is. It has been lithographed in India, but never printed or translated.

- Cheikh Nefzaoui, Le Livre d'Amour de l'Orient-Le Jardin Parfumé, Paris, 1912.

- Neville Spearman, The Perfumed Garden of the Shaykh Nefzawi, London, 1963. 


\section{Texts and Documents}

Apart from Burton's smothered translation the most famous of all these books is probably one called The Return of the Old Man to his Striving for Virility. This was originally written in Arabic by Ahmed bin Yusuf, commonly called Ibn Kamal. It was translated into Turkish for Sultan Selim II (1566-1574) and then into Persian. It was printed in Egypt in 1878 under the title of The Water of Life and finally had the honour of being translated into English in 1898 and published in a limited edition in Paris with the title The Old Man Young Again.

I do not propose to describe this book any further as it is not Persian and several more typical works were written in the seventeenth and eighteenth centuries when the Safavid shahs were ruling. The manuscript that I have selected as an example is also very well known throughout Persia. Copies are to be found in all the big libraries of that country. There is also a copy in London and another in Paris. It was lithographed in Teheran in 1886 and that is the nearest that it has got to print or translation.

The name of this work is Khirqa-i-Khanum dar 'Ilm-i-Tibb (Women's Patches in the Science of Medicine). It was written by one Murteza Quli bin Hassan Shamlu and is dedicated to Shah Sulayman Safavi (1666-1693). Murteza was the Civil Governor of the Holy City of Qum and while holding this post was decorated with the title Shamshir Bardar or Sword Bearer to the Shah. Later he was transferred as Governor of the large and important province of Khorasan and was killed by the Afghans in the siege of Merv.

There is no chapter on anatomy in this book. The author at once launches into the subject of sterility in women in chapter one which is headed 'On Putting into Motion the appearance of a Son from the Loins'. He then gives tests to settle that ever doubtful question 'Who is to blame for a fruitless union, the male or the female?' One test, he says, is to throw the semen of the man into a pail of water and into another pail that of the woman (by this he means the uterine discharge). A fertile semen will sink because coction within is complete. A non-fertile semen will float. Or again:

Place some barley or peas or beans in two separate saucers. Let the man and the women each pass urine into the saucers once daily. If both vessels turn green and neither dries up, then the cause of the sterility lies within the woman. If neither turn green and both dry up, then the cause lies within the man.

If this does not give a definite result, then a further test must be employed. The woman must apply to her vagina something with a bitter and sharp taste, such as aloes or colocynth. If the bitterness and sharpness mount to her brain, then there is no fault in her. Or again, let the woman apply to her vagina anything with a very good or a very bad smell. Then make someone smell her breath. If the smell is perceptible within her mouth, then no fault lies in her.

Chapters two and four are purely erotic. Chapter three is a guide to the hair and its care.

Chapter five discusses the other great problem which troubles every pregnant woman-the sex of her foetus. The following are the diagnostic signs. A male foetus will tend to lie on the right of the mother. The first sign of a male pregnancy will appear in the right breast. In the case of a male pregnancy the milk of the mother will be thicker and if a drop is placed on a mirror it will seem more opaque than usual. If placed in the sun it will look like quick-silver or a pearl. The colour of the mother's nipples tends to be red. The pulse at her right wrist is more full and more frequent than that at the left. When the woman stands up and begins to walk, she usually puts 


\section{Texts and Documents}

the right foot forward first. And finally a male foetus will quicken at the end of three months, a female at the end of four.

The belief that foetal sex can be determined from the mother's milk was widespread. Thus, al-Qazvini (born 1281) wrote: 'If it is desired to know whether it is a girl or a boy within the womb, then squeeze out some of the mother's milk on to the palm of the hand and cast into it a louse. If it makes its way out of the milk, then the child will be a girl and if it does not, then a boy. For the milk of a woman who carries a boy is thick and does not give passage to the louse'. ${ }^{6}$

This difference in the quality of the breast-milk of a son-bearing and a girl-bearing woman was sometimes of medico-legal importance. In one of the tales told in The Arabian Nights there is an Arab equivalent of the Judgement of Solomon. It occurs in Night 410. Two women being sisters and living in the same house were delivered in one night by the same midwife. One bore a male child and one a female. The female infant died, the male survived. Both mothers claimed the living child as hers. They appealed to the Ruler. 'The wazir cried: bring me two eggs and void them of their contents and see that the shells be clean empty. Then he commanded that each of the women drain somewhat of the milk from her nipple into the egg shell until she had filled it ... After this he placed both eggs in the balance pan and raising it aloft from its rounded stand perceived that one was weighty and the other was light. Quoth he: The milk of the woman in this egg is the heavier and she is the mother of the boy babe'.

Returning to the Khirqa-i-Khanum. There is introduced in chapter six the strange psychological theory, which the Persians held, that the seat of passion in a woman lies in a different organ each day. Here the author discusses how to determine which is the proper organ to stimulate on any particular day. Then follow several chapters on drugs, laying special emphasis on aphrodisiacs. Chapter twenty is of particular interest, for it is headed 'Stupefacient Spells and Drugs, quoted from the book and personal experience of Mirza Qadi'. Mirza Qadi was the son of Kashif-ul-Din, a court physician to Shah Abbas I (1587-1629). The Mirza died in 1664.?

The remaining chapters are on a variety of subjects, including one chapter on opium addiction (a very common failing in those times), two chapters on piles and their treatment, and a prescription for all kinds of venereal disease, said to have been composed by a European doctor. The book concludes with a little verse:

Rejoice, for my song in this Robe has been sung.

The patched cloak ('khirqa') of the Master has passed to the Young.

I have only space enough to discuss one of these medieval gynaecological manuals. There is another preserved in the Cambridge University Library, called The Mirror of Beauty, which was composed by Mohamed Baqir Ali Khan, court physician to Sultan Husayn Shah Safavi (1694-1722). If translated, this would I feel sure be of enormous interest and would probably confirm my view that these manuals are not indecent, erotic works, but are serious medical treatises which represent the final stage in the development of gynaecology before the whole system of medieval Persian medicine collapsed in front of the onrush of western science.

CYRIL ELGOOD

- al-Qazvini, Nuzhat-ul-Qulub (Stephenson's translation), p. 45.

In this subject a longer discussion than is here fitting will be found in C. Elgood, A Medical History of Persia, Cambridge University Press, 1952. 